WMJ (Warmadewa Medical Journal), Vol. 5 No. 2 November 2020, Hal. 48-59

\title{
External and Internal Customer Perceptions on Quality of Health Services at the Dental and Oral Hospital of Mahasaraswati University Denpasar
}

\author{
Made Leonita Purnama Dewi ${ }^{1}$, Rina Listyowati ${ }^{2}$, Nyoman Mangku Karmaya ${ }^{3}$ \\ Ilmu Kesehatan Masyarakat, Fakultas Kedokteran, Universitas Udayana, Jl. P.B. Sudirman,Denpasar. \\ Email $^{1}$ : leonita.29.3a8@gmail.com
}

\begin{abstract}
Oral and dental health problems in Bali are still relatively high at $57.6 \%$. As the only specialized dental hospital in Bali, RSGM needs to always maintain and improve the quality of health services, so as to increase people's desire for dental and oral care. This research was conducted to determine the quality of health services at the RSGM Mahasaraswati University Denpasar from the perspective of external and internal customers based on the five dimensions of Dabholkar, to find out the differences perceptions of external and internal customers based on the five dimensins of Dabholkar and their individual characteristics. This research is a cross sectional analytic. The sample was measured using a questionnaire with sample size of 112 external customers and 129 internal customers. The perception of external and internal customers on the quality of health services at the RSGM Mahasaraswati University Denpasar was mostly good: external customers $(50.9 \%)$ and internal customers $(52.0 \%)$. The results of statistical test analysis using chi-square $(\alpha=5 \%$; $p$-value $\leq 0.05)$ found that there were differences in perception between external and internal customers in physical aspects $(0.04)$ and policy $(0.00)$; there were differences in perception of the age characteristics $(0,00)$ and the level of education $(0,03)$. External customer perceptions on the physical aspects, reliability, personal interaction, and problem solving were good, but in the policy dimension they had poor perceptions. Internal customers had good perceptions on the aspects of reliability, personal interaction, problem solving and policies, but on the physical aspects they had poor perceptions. Based on the age characteristics, there was a difference in perception; aged $<28$ years had a good perception, while those aged $\geq 28$ years had less perception. RSGM Mahasaraswati Denpasar University needs to improve the quality of health services, especially in the physical and policy aspects so that can meet customer expectations.
\end{abstract}

Key words: External and internal customer perception, quality of health services.

\begin{abstract}
Abstrak
[Persepsi Pelanggan Eksternal dan Internal pada Mutu Pelayanan Kesehatan di Rumah Sakit Gigi dan Mulut Universitas Mahasaraswati Denpasar]

Masalah kesehatan gigi dan mulut di Bali masih tergolong tinggi yaitu sebesar 57,6\%. RSGM sebagai satu-satunya rumah sakit khusus gigi di Bali perlu selalu menjaga dan meningkatkan mutu pelayanan kesehatan, sehingga dapat meningkatkan keinginan masyarakat akan perawatan gigi dan mulut. Tujuan dari penelitian ini adalah untuk mengetahui persepsi pelanggan eksternal dan internal pada mutu pelayanan kesehatan di RSGM Universitas Mahasaraswati Denpasar berdasarkan 5 dimensi Dabholkar, untuk mengetahui perbedaan persepsi pelanggan eksternal dan internal berdasarkan 5 dimensi Dabholkar dan berdasarkan karakteristik individu masing-masing. Penelitian ini merupakan penelitian cross sectional analytic. Alat ukur pada penelitian ini menggunakan kuesioner dengan jumlah sampel 112 pelanggan eksternal dan 129 pelanggan internal. Persepsi pelanggan eksternal dan internal terhadap mutu pelayanan kesehatan di RSGM Universitas Mahasaraswati Denpasar sebagian besar baik yaitu pada pelanggan eksternal (50,9\%) dan pelanggan internal (52,0\%). Hasil analisis uji statistik menggunakan chi-square $(\alpha=5 \%: p$-value $\leq 0,05)$ didapatkan bahwa ada perbedaan persepsi antara pelanggan eksternal dan internal pada aspek fisik $(0,04)$ dan kebijakan (0,00), terdapat perbedaan persepsi pada karakteristik usia $(0,00)$ dan tingkat pendidikan (0,03). Persepsi pelanggan eksternal pada aspek fisik, reliabilitas, interaksi personal, dan pemecahan masalah adalah baik, namun pada dimensi kebijakan memiliki persepsi yang kurang. Pada pelanggan internal memiliki persepsi yang baik pada aspek reliabilitas, interaksi personal, pemecahan masalah dan kebijakan, namun pada aspek fisik memiliki persepsi yang kurang. Berdasarkan karakteristik usia terdapat perbedaan persepsi yaitu usia $<28$ tahun memiliki persepsi yang baik sedangkan usia $\geq 28$ th memiliki persepsi kurang. RSGM Universitas Mahasaraswati Denpasar perlu meningkatkan mutu pelayanan kesehatan terutama pada aspek fisik dan kebijakan sehingga dapat memenuhi harapan pelanggan.
\end{abstract}

Kata Kunci: Persepsi pelanggan eksternal dan internal, mutu pelayanan kesehatan. 


\section{INTRODUCTION}

Dental and oral health is essential as it is the basic of overall health for each individual. World data from WHO shows that around $60-90 \%$ of schoolchildren and almost $100 \%$ of adults experience dental caries which causes discomfort and disruption of activities. Approximately $15-20 \%$ of $35-44$ years olds suffer from periodontal tissue disease which leads to tooth loss; and $30 \%$ of people aged $65-74$ years old do not have real teeth. ${ }^{1}$

Proportion of dental and oral problems in Indonesia is quite high, which is $57.6 \%$, while the proportion of people in Indonesia who got health service from dental healthcare is only $10.2 \%$. Dental and oral problems in Bali is $57.6 \%$, however, people with dental healthcare access is $15 \%$. In Denpasar, people with dental and oral problems is $15.6 \%$, while the people who have got the dental service from dental medical professionals is $46 \%{ }^{2}$

Good quality service from provider can influence the patients' decision on revisiting the service in a hospital. According to Fidyawati et al. (2015) patients' perception on service quality is associated with patients' intention to revisit. Service quality is assessed based on some indicators, such as profession aspects, management aspects, and customer aspects. Profession aspects includes attentiveness, swiftness, responsiveness on giving information, and the accuracy of diagnosis. Management aspects includes performance and swiftness of provider in giving service, while customer aspect is the customer satisfaction on the facility of the hospital. ${ }^{5}$

Healthcare service is an important thing to consider, as explained by Alfi Febriana (2013) on the study of quality of healthcare service based on dabholkar dimension in hospital wards, which says physical aspects, reliability, personal interactions, problem solving, and regulations are important for patients, however, there are several sub-dimension needs improvement, such as physical aspects (medical appliances, rooms' name directory, cleanliness of the inpatient wards) and personal interaction (e.g. hospitality and attentive- ness of physicians to patients). ${ }^{6}$

Quality of service is not only seen from the external customers' perspective as the receiver of the service, but can also be seen from internal customers' perspective as the service provider. Study by Miswar, (2011) in Sorolangun primary healthcare center found that there was difference perception between patients and provider in term of responsibility and assurance. Difference perception observed in the responsiveness of the provider which deemed slow by the patients, while, the provider's service needs to meet the standard and not all the problems were able to be solved considering the primary healthcare center's resources. The perception on the long waiting time experienced by the patients was also difference from provider's perception, where the number of patients was disproportionately higher compared to the number of examination rooms, which were only two rooms, and this affected the service time. Difference perception on the hospitality was also observed; patients felt that the providers were not friendly, but on the other hand, the providers felt that their conducts were already cordial. ${ }^{7}$

Assessment on quality of healthcare service will be accurate if it is seen from both perspectives of internal customers as the service providers of the healthcare and perspective of external customers as the receiver of the healthcare service. The biggest dental and oral healthcare service in Bali, particularly in Denpasar, is The Dental and Oral Hospital of Mahasaraswati Denpasar (RSGM Mahasaraswati), which is the referral hospital for dental and oral diseases. RSGM Mahasaraswati is type B special hospital which consists of integrated RSGM and regular RSGM, where the service of integrated RSGM are conducted by competent dentists, while service of regular RSGM is carried out by students of dentistry profession, where the cases being handled are simpler. ${ }^{3}$

As the only dental and oral hospital in Bali and has operated since 2002, RSGM mahasaraswati Denpasar has never been evaluated related to the quality of its health service. A preliminary study on 26 
October 2017 through interviewing the Director of RSGM Mahasaraswati and data collection by questionnaire on 10 respondents found that there was no complaints regarding to the dentists at the integrated RSGM, however there were some complaints regarding to the regular RSGM.

Preliminary study found that the average waiting time of patients was more than 60 minutes, while according to SPM on Regulation of Ministry of Health No 129 Year 2008 stated that maximum waiting time for outpatient service is 60 minutes. ${ }^{4}$ In addition, providers also complained about the facilities such as dysfunction dental unit which led to delayed service to the patients.

The number of patient visits to regular clinic of RSGM fluctuated during 2014 - 2017. In 2014, the number of patient visits reached to 5.239 patients; and there was $15 \%$ increase in 2015 with number of visits of 6.039 people; while in 2016, the number of visits decreased as many as $28 \%$ into 4.334 people, and the declining number of visits was also observed in 2017 to 4094 people.

Personal interaction between patients and providers is also deemed important to patients; not only informative communication, but also involving emotional and psychological states of the patients. Patients consider the personal interactions from various perspectives, which could be linked with specific subdimension such as provider's reliability, responsiveness, guarantee and empathy. While, on provider side, the emphasis is in the importance of professional skills. ${ }^{8}$

Quality service of RSGM is highly affected by providers, facilities, and healthcare service system. ${ }^{9}$ Most of the providers do not know the type of services needed by the patients, thus, this study aimed to determine the quality of health service in RSGM Mahasaraswati Denpasar from the perspective of external and inter- nal customers and later be used as reference to improve the quality of the healthcare.

\section{METHOD}

This study obtained ethical clearance from Ethical Committee of Litbang FK/UNUD and has been declared ethically appropriate with approval number: 1647/ UN14.2.2.VII.14/LP/2019 issued on 27 May 2019. This study used cross sectional analytic design which conducted at one point in time to determine the difference perception of customers on the quality of healthcare service at RSGM Mahasaraswati University Denpasar. This study was carried out at RSGM in March - July 2019.

Sample was selected by simple random sampling method: every patient who just left the treatment room with odd order of number and already done with the treatment were recruited as research sample. Sampling of profession students were conducted by purposive sampling where the respondents were selected based on predefined criteria. This method was chosen because the students could not be gathered at once due to different schedule in profession works, thus the samples were those who were not working at that time.

Sample size calculation was done using sample size $\mathrm{WHO}$, and the minimum sample size was 112 for external customers and 129 for internal customers. The inclusion criteria for students of profession program were those recorded in FKG in 2019, were present at FKG campus, students of profession program with working experience $\geq 1$ year; while, the criteria for patients were patients aged $\geq 17$ years old.

This study used questionnaire which consists of characteristic data of patients and providers; they were age, gender, education level, and class year. The questionnaire used Likert's scale, where the answers of each item were ordered from the 


\section{WMJ (Warmadewa Medical Journal), Vol. 5 No. 2, November 2020, Hal. 51}

most positive statement to the most negative one. For 'very good' answer was scored as 5 ; the score 4 was given to answer 'good'; score 3 for answer 'doubt'; score 2 for answer 'poor'; and score 1 is given to answer of 'very poor'. The questionnaire consisted of 35 items divided into 5 dimensions according to Dabholkar. First dimension was physical aspect which further divided into 2 sub-dimensions: facility and physical appearance. Second dimension was reliability, and the following dimensions were personal interaction, problem solving, and regulation. For every statement, the respondents must circle one of the option response according to their experience. Total score were then classified into two categories, which were good and poor.

\section{RESULTS}

Table 1 shows that most of 112 external customers $(53.5 \%)$ were $\geq 28$ years old, while, most of 129 internal customers $(95.3 \%)$ were $<28$ years old. Gender characteristic revealed that most of the external and internal customers were female, which were $62.5 \%$ and $60.0 \%$, respectively. Based on the level of education, most of external customers $(81.2 \%)$ had high education level and small proportion (19.0\%) had low education. Based on class year, most of the internal customers $(73.6 \%)$ were students of profession program of year $\geq 2014$, while the rests $(26.3 \%)$ were students of class year $<2014$.

\section{Characteristics of External Customers and Internal Customers}

Table 1. Characteristics on age, gender, level of education, and class year

\begin{tabular}{|c|c|c|c|c|c|}
\hline \multirow{2}{*}{$\begin{aligned} \text { No. } \\
1 .\end{aligned}$} & \multirow[t]{2}{*}{ Characteristics } & \multicolumn{2}{|c|}{ External Customers } & \multicolumn{2}{|c|}{$\begin{array}{c}\text { Internal } \\
\text { Customers }\end{array}$} \\
\hline & & Freq. & $\%$ & Freq. & $\%$ \\
\hline & a) $<28$ years & 52 & 46.4 & 123 & 95.3 \\
\hline & b) $\geq 28$ years & 60 & 53.5 & 6 & 4.7 \\
\hline
\end{tabular}

2. Gender
a) Male
42
37.5
55
40.3
b) Female
70
62.5
77
60.0

3. Level of education
a) Low
21
19.0
b) High
91
81.2

4. Class year
a) $<2014$
34
26.3
b) $\geq 2014$
95
73.6 


\section{Quality Perception of External and Internal Customers Based on Dabholkar Dimen-} sions

Table 2. Analysis of difference on quality perception based on Dabholkar dimensions

\begin{tabular}{|c|c|c|c|c|c|c|}
\hline \multirow{2}{*}{ No. } & \multirow{2}{*}{$\begin{array}{c}\text { Dabholkar Dimension / RSGM } \\
\text { customers }\end{array}$} & \multicolumn{4}{|c|}{ Quality perceptions } & \multirow{2}{*}{ p-value } \\
\hline & & \multicolumn{2}{|c|}{ Good } & \multicolumn{2}{|c|}{ Poor } & \\
\hline \multirow[t]{3}{*}{1.} & Physical aspects & Freq. & $\%$ & Freq. & $\%$ & 0.04 \\
\hline & a) External customers & 70 & 62.5 & 42 & 37.5 & \\
\hline & b) Internal customers & 64 & 49.6 & 65 & 50.3 & \\
\hline
\end{tabular}

2. Reliability

$\begin{array}{lllll}\text { a) External customers } & 61 & 54.4 & 51 & 45.5 \\ \text { b) Internal customers } & 66 & 51.1 & 63 & 48.9\end{array}$

0.60

48.9

3. Personal interactions

$\begin{array}{lllll}\text { a) External customers } & 68 & 60.7 & 44 & 39.2 \\ \text { b) Internal customers } & 88 & 68.2 & 41 & 31.8\end{array}$

4. Problem solving

a) External customers

82

73.2

66.7

30

26.8

b) Internal customers

86

66.7

43

33.3

0.27

5. Regulations
a) External customers
54
48.2
58
b) Internal customers
94
72.9
35
51.8
27.1

0.00

6. Total perception
a) External customers
57
50.9
55
49.1
b) Internal customers
67
52.0
62
48.0

Table 2 shows that most of the external customers $(62.5 \%)$ had good perception on physical aspect dimension in RSGM, while, most of the internal customers $(50.3 \%)$ had poor perception. On dimension of reliability, personal interaction, and problem solving, most of the external customers and internal customers had good perception. On regulation dimension, most of the external customers $(51.8 \%)$ had poor perception, whereas, the perception of internal customers on the same dimension were mostly $(72.9 \%)$ good.

The overall perception on quality dimensions revealed that most of the external customers $(50.9 \%)$ had good perception, and similar result was also observed on the internal customers, where most of them $(52.0 \%)$ had good perception on the quality of health service of RSGM. There were differences on perception between external customers and internal customers on the physical aspect and regulation aspect with $p$-value of $\leq 0.05$ and 0.00 , respectively. 
Table 3. Difference perception on quality based on Dabholkar subdimensions

No. Subdimension Dabholkar/ RSGM customers

Quality perceptions

\begin{tabular}{cccc}
\hline & Good & & \multicolumn{2}{c}{ Poot } \\
Freq. & $\%$ & Freq. & $\%$
\end{tabular}

1. Dental chair system
a) External customers
107
$95.0 \%$
5
$4.46 \%$
b) Internal customers
61
$47.7 \%$
68
$52.3 \%$

2. Saliva Ejector
a) External customers
57
$50.4 \%$
55
$49.5 \%$
b) Internal customers
59
$46.1 \%$
70
$54.0 \%$

3. Provider discussion

$\begin{array}{lcccc}\text { a) External customers } & 46 & 41.0 \% & 66 & 59.0 \% \\ \text { b) Internal customers } & 120 & 92.7 \% & 9 & 7.3 \%\end{array}$

Table 3 shows that there was difference in perception on sub-dimension of dental chair system at RSGM. Most of the external customers had good perception $(95.0 \%)$, while internal customers mostly had poor perception (52.3\%). On saliva ejector sub-dimension, most of the external had good perception (50.4\%), while internal customers mostly had poor perception $(54.0 \%)$. On provider discussion sub-dimension, most of the external customers $(59.0 \%)$ had poor perception, while internal customers mostly had good perception $(92.7 \%)$. 


\section{Quality Perception of External and Internal Customers Based on Individual Charac- teristic}

Table 4. Analysis of difference on quality perception based on individual characteristics

No. Characteristics Good Poor

$\underset{\substack{p-\\ \text { value }}}{\text { and }}$

External Internal $\quad$ External $\quad$ Internal

\begin{tabular}{lccccccccc}
\hline 1. Age & Freq. & \% & Freq. & \% & Freq. & \% & Freq. & \% & 0.00 \\
a) Age $<28$ & 28 & 29.8 & 66 & 70.2 & 24 & 29.6 & 57 & 70.3 & \\
b) Age $\geq 28$ & 29 & 96.7 & 1 & 3.33 & 31 & 86.1 & 5 & 13.9
\end{tabular}

2. Level of education

0.03
a) Low
$15 \quad 71.4$
$6 \quad 28.5$
b) High
$42 \quad 46.1$
$49 \quad 53.9$

Table 4 shows the comparison of perception based on customers' characteristics. Most of external and internal customers aged $<28$ years old $(29.8 \%$ and $70.2 \%$, respectively) had good perception on the quality of health service at RSGM, while customers aged $\geq 28$ years old mostly ( $86.1 \%$ and $13.9 \%$, respectively) had poor perception on the quality of health service at RSGM.

On the level of education characteristic, most of the external customers who had low level of education (71.4\%) had good perception towards the quality of health service at RSGM, while most of external customers with high level of education $(53.9 \%)$ had poor perception towards the quality of health service at RSGM.

It is evident that there was difference perception based on age characteristics both in external and internal customers, and also there was difference perception based on the level of education of external customers.

\section{DISCUSSION}

Quality Perception of External And Internal Customers Based On Dabholkar Dimensions

Perception of external and internal customers on quality of health service at RSGM Mahasaraswati University Denpasar was good, which external customers' perception scored highest on the problem solving dimension compared to the other dimensions. Whereas, internal customers' perception was scored the highest on the regulation dimension compared to the other dimensions. There were some aspects deemed as poor by both external customers and internal customers, such as the insufficient number of dental chairs, dysfunction of system on dental chairs which controls the patient's sitting position, dysfunction of saliva ejector, and absence of description for the service pathway. Comparison analysis of perception between external customers and internal customers towards the five dimensions of health service quality at RSGM Mahasaraswati University Denpasar has shown that there were difference perceptions on the physical aspect and regulation aspect; while the perceptions on the reliability, personal interaction, and problem solving aspects did not differ between the two types of customers. The difference was indicated by the fact that most of the external customers stated that the physical aspect at the RSGM Mahasaraswati was good, but on the contrary the internal customers deemed the physical aspect was poor.

The poor perception of physical aspects by the internal customers was 
mostly on the insufficient number of dental chair; the insufficient number of the dental chair were only experienced by the students of profession program as the internal customers. The number of profession program students of normal round $(\geq 2014)$ was 127 students and the number of students of class year $<2014$ was 114 students, while the available number of dental chair were only 78. Thus, the students could not treat the patients concurrently. The patients did not directly experience the lack of dental chair, however, the patients indirectly impacted by it as the waiting time for getting treatment from profession program students became long.

The available dental chairs at RSGM, as the supporting performance of the providers on health service, had some inadequacies. Based on this study, the internal customers had poor perception on the saliva injector and the controlling system for patient sitting position on the dental chairs. The defect on the saliva injector could hinder the work of the providers during patient treatment. The providers had to interrupt the patients to spits for several times, thus the treatment time became longer. The same problem occurred on the controller for patient sitting position on the dental chairs which led to difficulty for providers to control the patient position during treatment. On the other hand, the patients as the external customers had good perception on the saliva and the dental chairs because the patients did not know the proper function for those devices.

Study by Ristiani (2017) Has shown that facilities at IPDN Jatinangor Clinic was an important physical aspect. It is stated that the facility at IPDN Jatinangor Clinic was significantly associated with the quality of the service. The completeness of facility in a healthcare institution is not enough to increase the patient satisfaction. By maximizing the use and function of the facilities could increase the patient satisfaction toward receiving the health service. ${ }^{10}$

The assessment of health service quality is not only seen from patients' perspective, but also from the providers' perspective. Study by Miswar (2011) on the difference perceptions between patients and healthcare providers on the quality of the outpatient service at Sarolangun Primary Healthcare center, has concluded that there was difference in perception between external customers and internal customers. The difference perceptions were observed on the dimensions of responsibility and assurance, which the providers felt that they quickly respond to the patients' complains, and also stated that waiting time was short, and had been friendly during the service; however, the patients thought the contrary. ${ }^{7}$

The disagreement of perception between external and internal customers was also observed on the regulation dimension. Providers considered the regulations at RSGM Mahasaraswati University Denpasar as good, especially on the point of discussion with the lecturers prior to patient treatment. That point was the provision stipulated by the faculty on the providers to control every treatment given by providers to the patients; difference with providers, patients considered the opposite.

Each provider at RSGM Mahasaraswati University Denpasar who would treat patients had to always discuss with lecturer, both before giving the treatment and during the treatment. Discussion was one of the method used by lecturers to grade the providers. The importance of discussion on each treatment was unacknowledged by patients, thus, there was difference perception between external and internal customers.

The other shortfall of regulation sub-dimension aspect was on the service pathway directory which was not displayed at RSGM. On that sub-dimension, perceptions from both external and internal customers were the same, both had poor perception on the service pathway at RSGM Mahasaraswati. At the time of this study was conducted, there was no display of the service pathway at RSGM Mahasaraswati. The service pathway directory at hospitals will help patients to utilize the services, from the time patients proceed with administration process, to treatment and until patients exit the facility. 
Radito, (2014) on his study stated that patient perception is affected by several factors, one of them is the hospital regulation. Hospital regulation such as administration process at the hospital start from the patient registration upon admission, administration during treatment, until administration at the end of the treatment, could affect the patient's perception towards the quality of hospital. The same finding was stated in the study by Baharuddin, et al (2016) which explained that regulations of a hospital is required because it influences the desire of people to re-utilize the health service. Factors which support the hospital regulation is the regulation that not complicate people in getting the health service. ${ }^{11,12}$

\section{Quality Perception of External and In- ternal Customers Based on Individual Characteristics \\ Perception based on age}

Age is the living duration of respondents calculated since their birth year. Result of the analysis showed that there was a significant difference in perception based on age. On the age group of $<28$ years old, the perception was good, while the perception of respondents aged $\geq 28$ years old was poor. Patients aged $<28$ years old were more understand on the acquired health service compared to patients on the age group of $\geq 28$ years old, thus, patients on the age group $<28$ years old were more likely to have good perception towards the quality service.

Some of the providers aged $\geq 28$ years old were also students of $<2014$ class year, whom were students with additional round (study period of $1.5-2.5$ years) and intensive round (study period $>2.5$ years). Those students had more experience as profession program students, such as experiencing the similar cases repeatedly, or getting more experience from their peer students of the same class year. Thus, the internal customers aged $\geq 28$ years old had more determination and demand on several aspects which could support providers' performance in delivering better service.

The finding is in accordance with the study by Rizal dan Jalpi (2018) which stated that there was significant correlation between age and patients' perception on the quality of health service at Bajarmasin Primary healthcare centers. The study explained that younger respondents had good perception on the quality service at the primary healthcare centers compared to older patients which had poor perception on the quality service at the primary healthcare centers. As the older the age of the patients, the more experiences they had, thus, older patients have higher expectation on receiving health service. ${ }^{13}$

Sumarwan, (2004) also revealed that age category caused the difference perception or interest to service. An individuals on their adult age are having a way of thinking that are more critical and optimum, thus, affecting the judgment towards a product. The same goes to providers, as the older the providers, the more experienced they are, thus, providers are more likely to not satisfied with the medical service being delivered ${ }^{14}$

\section{Perception based on gender}

Gender is a biological characteristic of respondents since birth. In this study, male respondents tend to have poor perception, while, female respondents tend to have good perception. However, result of the analysis showed that there was no significant difference in perception based on gender. Gender of external customers and internal customers were not significantly different because of many factors underpinning perception, such as knowledge, experience, interest, motivation, etc.

Study by Bambang Irawan (2018) also mentioned that gender does not affect the perception on quality of health service, as both male and female have the same risk in receiving healthcare service. In addition, way of thinking of male and female are equal nowadays. Equality of way of thinking between male and female was set off by the gender equality, which occurred through long social process, always changing and improving from time to time. ${ }^{15}$

Anson et al. (1993) concluded that 
the absence of difference perception between male and female towards health could be influenced by several factors such as education background, occupation, family environment, and life pressure. Those factors could have lessen the difference in perceptions between genders. Biological health also plays indirect role on perception towards health. ${ }^{16}$

\section{Perception based on level of education}

Level of education is the last formal education of respondents and has been awarded graduation certificate. Results of the analysis showed that there was significant difference in perception on level of education variable. This study found that most of the patients with high education $(\geq$ middle high school) had poor perception towards the quality of RSGM, while, most of the patients with low education ( $\leq$ junior high school) had good perception. This difference in perception was because of patients with high education tend to have high demand and expectation towards the service of RSGM compared to patients with low education.

Study by Kuntoro dan Istiono (2017) also found the same result, that there was a significant difference in perception of patients based on their level of education. Patients with low education mostly satisfy with quality of service at primary healthcare center of Kretek Bantul Yogyakarta compared to the patients with high education which mostly had poorer perception. $^{17}$

One's level of education could affect one's perception towards the quality service (Hanifah Lina, et al 2013) the higher the education level, the better understanding on the health, thus, the higher the demand and expectation towards the health service. On the other hand, respondents with low education mostly received the health service without exceeding expectation. Respondents with high education were likely to feel less satisfy towards the health service delivered by healthcare providers compared to respondents with low education. $^{18,19}$

\section{Perception based on class year}

Class year is the year of provider's registration as students of FKG Mahasaraswati University Denpasar. Analysis has shown that there was no significant difference in perception based on class year category. Providers of $<2014$ class year tended to have poor perception, while providers of $\geq 2014$ class year had good perception. That was so because the providers of $<2014$ had $>2.5$ years of working duration compared to class year of $\geq 2014$ who had 1 year working duration. Longer working duration gave longer working experience and allowed better awareness on the insufficient facility at RSGM during the period. This reinforced internal customers of $<2014$ class year to have more demand toward the RSGM facility thus they showed poorer perception towards the quality service of RSGM.

Previous study by Sujianto et al (2014) also concluded similar result that there was no association between level of education and providers' perception. Relationship with colleagues could affect the providers' satisfaction, that when the relation between co-workers is good then there will be comfort and satisfaction about the job which lead to maximum service to the patients. ${ }^{20}$

\section{CONCLUSIONS}

Perception of external and internal customers on quality of healthcare service at RSGM Mahasaraswati University Denpasar were mostly good, however, perception of external customers on regulation dimension was poor, and the internal customers had poor perception on the physical aspect.

There were differences in perceptions between external and internal customers according to Dabholkar dimensions, which were on physical and regulation aspects. There was difference perception from different age groups. External and internal customers aged $<28$ years old mostly had good perception, while customers aged $\geq 28$ years old had poor perception. 


\section{AKNOWLEDGEMENTS}

Author would like to express appreciation to first and second authors as well as Public Health Faculty of Udayana University for feedbacks and support during this study.

\section{REFERENCES}

1. World Health Organization. 2015. Oral Health (serial online), Feb.-May., [cited 2016 Aug. 8]. Available from: URL: https://www.who.int/.

2. Kementrian Kesehatan RI, 2018. Riskesdas 2018. Jakarta: Badan Penelitian dan Pengembangan Kesehatan Departemen Kesehatan Republik Indonesia.

3. FKG Unmas Denpasar. 2017. Profil Fakultas Kedokteran Gigi Universitas Mahasaraswati Denpasar.

4. Menkes RI, 2008. Standar Pelayanan Minimal Rumah Sakit No. 129/Menkes/ SK/II/2008. , p.282.

5. Fidyawati, Linda. Yennike Tri Herawati, Eri Witcahyo. 2015. Hubungan antara Persepsi Mutu Pelayanan dengan Minat Kunjungan Ulang di Instalasi Rawat Jalan RSD Balung Kabupaten Jember. Jurnal Administrasi dan Kebijakan Kesehatan, Fakultas Kesehatan Masyarakat : Universitas Jember.

6. Alfi Febriana Rahmawati, S.S., 2013. Mutu Pelayanan Kesehatan Berdasarkan Dimensi Dabholkar di Ruang Rawat Inap Penyakit Dalam. administrasi kesehatan Indonesia, 1, pp.132139.

7. Miswar, Irwan., 2011. Perbedaan Persepsi Pasien dengan Petugas terhadap Mutu Layanan Rawat Jalan di Puskesmas Sarolangun tahun 2011.

8. Globenko, A. \& Sianova, Z., 2012. Service quality in healthcare: quality improvement initiatives through the prism of patients' and providers' perspectives. Umeå School of Business and Economics, pp.1-138.

9. Assaf, AF. 2009. Mutu Pelayanan Kesehatan, First Edition. Jakarta : EGC

10. Ristiani, Ida Yunari. 2017. Pengaruh sarana prasarana dan kualitas. , VIII, pp.155-166.

11. Radito Th. A. 2014. Analisis Pengaruh Kualitas Pelayanan dan Fasilitas Kesehatan Terhadap Kepuasan Pasien Puskesmas Jurnal Ilmu Manajemen Vol 11 No.2. STIE IEU Yogyakarta.

12. Baharuddin Martini, Nur Asphina R.Djano, I Wayan Djuliarsa. 2016. Pengaruh Kualitas Pelayanan Kesehatan Terhadap Minat Pasien Dalam Memanfaatkan Kembali Jasa Pelayanan Rawat Jalan di Puskesmas Wara Utara Kecamatan Bara Kota Palopo Tahun 2016. The Influence Of Health Service Quality To The Patient Interest In Using The Outpatient Service. Stikes Mega Buana Palopo.

13. Rizal, Achmad dan Agus Jalpi. 2018. Analisis Faktor Internal Penentu Kepuasan Pasien Puskesmas Kota Banjarmasin. Al Ulum Sains dan Teknologi Vol. 4 No. 1. Fakultas Kesehatan Masyarakat Universitas Islam Kalimantan Muhammad Arsyad Al Banjari Banjarmasin.

14. Sumarwan, U. 2004. Perilaku Konsumen: Teori Dan Penerapannya Dalam Pemasaran. Jakarta: Ghalia Indonesia: Warta Konsumen.

15. Diska Widayani, Ni Made. Sri Hartati. 2014. Kesetaraan Dan Keadilan Gender Dalam Pandangan Perempuan Bali: Studi Fenomenologis Terhadap Penulis Perempuan Bali. Jurnal Psikologi Undip Vol.13 No.2, pp.149-162. Fakultas Psikologi Universitas Semarang.

16. Anson, O. et al., 1993. Gender differences in health perceptions and their predictors. Social Science and Medicine, 36(4), pp.419-427.

17. Kuntoro Wahyu, Wahyudi Istiono. 2017. Kepuasan Pasien Terhadap Kualitas Pelayanan Di Tempat Pendaftaran Pasien Rawat Jalan Puskesmas Kretek Bantul Yogyakarta. Vol 2. No 1. Jurnal Kesehatan Vokasional. Fakultas Universitas Gajah Mada.

18. Hanifah, Lina, Antono Suryoputro, S.P.A., 2013. Faktor-Faktor yang Berhubungan dengan Persepsi Terhadap Kualitas Layanan Pendaftaran Pasien Rawat Jalan Via SMS Gateway 
WMJ (Warmadewa Medical Journal), Vol. 5 No. 2, November 2020, Hal. 59

di RSUD Tugurejo Semarang. Journal of Chemical Information and Modeling, 53(9), pp.1689-1699.

19. Fatonah, Pendrita Jennie Kristina. Tavip Dwi Wahyuni. Wahidyanti Rhayu $\mathrm{H}$. 2017. Hubungan Amtara Kualitas Pelayanan Dengan Tingkat Kepuasan Pasien Rawat Jalan Pengguna BPJS di RSI G Kabupaten Malang. Journal
Nursing News, 2(1), pp.31-37.

20. Sujianto; Koeswo, Mulyatim; U Woro, E., 2014. Kepuasan Kerja Mempengaruhi Kinerja Pelayanan Operasi Elektif Job Satisfaction Affecting Elective Surgery Service Performance. Kedokteran Brawijaya, 28(1), pp.54-58 